\title{
RUSSELL ON HUME'S ACCOUNT OF THE SELF
}

\author{
Alan SCHWERIN \\ Philosophy / Monmouth U. \\ West Long Branch, NJ 07764-I898, USA \\ ASCHWERI@MONMOUTH.EDU
}

\begin{abstract}
The History of Western Philosophy enhanced Russell's broad reputation among members of the public and helped secure his finances. But the academic community was less enthusiastic about the text and tended to treat it with contempt. My paper is a critical investigation of one of the central chapters of Russell's History: namely, Russell's rendition of David Hume's views on the self. My argument is that Russell's concise treatment of le bon David's provocative views on the self must be read with great care-otherwise a misunderstanding of Russell's interpretation is likely to be foisted on this popular and influential twentieth-century text.
\end{abstract}

I respected Mr. Hume as the greatest Metaphysician of the Age.

(Thomas Reid, c. 1764)

he publication of A History of Western Philosophy in October
I945 marked the beginning of the end of the personal and fi-
nancial travails that characterized Bertrand Russell's six years in America. When Russell sailed for England in the summer of I944, he had with him a bulky manuscript, the publication of which would inaugurate a new, less traumatic phase in his life. His American experience had this time not been as pleasant as he had hoped. As Ray Monk summarizes it, while in America in the r940s Russell's "marriage had fallen apart, his relations with his oldest two children had come under intense strain and he had attracted the most vicious public opprobrium he had ever suffered" with the CCNY affair. ${ }^{1}$ The

1 Monk, Bertrand Russell, I92I-70, p. 273. 
contract from Simon and Schuster to produce a survey of western philosophical thought, "and Its Connection with Political and Social Circumstances from the Earliest Times to the Present Day" would help relieve Russell's financial distress and ultimately enhance his standing in the public eye. But the academic community remained unconvinced by Russell's synopsis of the ideas of some of the leading thinkers of the western canon and tended to treat the text with contempt.

Initially conceived as a series of lectures for Dr. Albert Barnes and delivered at his Foundation in Pennsylvania, Russell with the help of his third wife, Patricia Russell, compiled a series of short, engaging presentations on thinkers as diverse as the pre-Socratics, the Franciscan Schoolmen, Marx and Byron. When his contract with the Barnes Foundation was summarily cancelled in December 1942, Russell moved to Bryn Mawr where he had access to its excellent college library. Here the manuscript for his History of Western Philosophy was completed early in 1944, barely in time for the return trip to England. In the end Russell singled out an eclectic set of 35 thinkers for analysis, one of which was David Hume. As we might expect, it is Hume's philosophy of mind that features centre stage in the chapter on the Scottish philosopher. Does Russell do justice to this important component of Hume's work? This is the question I wish to address in this paper.

Russell's depiction of Hume's views on the mind, or the self, in $A$ Treatise of Human Nature is succinct. ${ }^{2}$ Not one to mince his words, Russell uses a mere twenty sentences to both present and critique the Scot's thought on the various thorny issues assembled on the self in the Treatise. ${ }^{3}$ And three of these sentences are actually quotations from Hume. So Russell relies on a mere seventeen sentences to explain and critically evaluate what are arguably two of the most intricate and challenging sections of the Treatise: Book I, Part Iv, Section v, "Of the immateriality of the soul", and Section VI, "Of personal identity". The issues in these sections, as Hume himself makes clear to his readers,

2 What about other publications from Hume that articulate his philosophy of mind? There are none-well, none that explicitly present and defend his account of the mind, or the self.

${ }^{3}$ See the appendix to this paper for the complete passage from the 1945 Simon and Schuster edition. My page and line numbers refer to that edition. 
are especially difficult to deal with, giving rise to conundrums that threaten to undermine any investigation into the problems of the self. Referring explicitly to his painstaking analysis in section VI, in the appendix of the Treatise Hume concedes that he is stumped:

But upon a more strict review of the section concerning personal identity, I find myself involv'd in such a labyrinth, that, I must confess, I neither know how to correct my former opinions, nor how to render them consistent.

(Treatise, p. 633)

This honesty is rare among philosophers. Coming as it does from one of the most exuberant, enthusiastic and talented thinkers of the Enlightenment, the admission is especially noteworthy. Yet when we turn to Russell for his rendition of Hume's account of the self there is not even a hint of the intellectual turmoil that Hume concedes underscores his bold ideas. This omission from the History is unfortunate, for the tone cast by Russell seriously misrepresents, if not distorts, the overall impression of Hume's analysis of the problems of the self.

When one considers the large picture of the self that Hume presents in the Treatise, two very distinct and different scenes emerge for our consideration: one is bold and confident, while the other is hesitant, flush with doubt and uncertainty. Ignore the appendix to the Treatise, as Russell does, and one is left with the impression that, in the main text of the Treatise, Hume is confidently asserting a bold, irreverent thesis on the self; namely, that there is none. But when one reads on and takes into consideration the frank deliberations in the appendix, one uncovers a more circumspect, unsure young Hume searching for a way out of the impasse that has emerged from his earlier, more forthright analysis. So when we turn to Russell's History of Western Philosophy for guidance on Hume's views of the self, we need to be cautious, for a crucial dimension of this influential account in the philosophy of the mind has been overlooked. The tone of Russell's characterization of Hume's account of the self is misleading. ${ }^{4}$ What now of its content?

4 To be fair to Russell, he is not alone in his willingness to downplay the influence of Hume's appendix. Due to its obscurity and brevity, scholars are reluctant to speculate about its relevance to the arguments in the main text. For instance, Justin BROACKES suggests that due to its opacity few readers will find the appendix of help in their attempts to follow the arguments in the main text. (See his "Hume".) However, in 
Is this not a more important issue for readers of Russell's History, one might wonder? Has Russell accurately portrayed the fundamentals of Hume's views on the self in his seventeen sentences? Here, I suggest, the evidence is mixed.

As Russell sees it, Hume's account of the self rests on two discrete pillars:

I. There is no impression of the self.

2. There is no idea of the self.

Let us consider each of these renditions of elements of Hume's account of the self. ${ }^{5}$ As I hope to demonstrate, Russell's interpretative claims are interesting and provide us with fascinating insights into Hume's views. However, as I shall also show, these proposals are to be treated with great care. Unless one treads cautiously one is likely to dismiss Russell's depiction of Hume as superficial and misleading, if not entirely false.

\section{THERE IS NO IMPRESSION OF THE SELF}

In the first place, as Russell sees it, Hume subscribes to a bold thesis on the impression of the self: there is none.

There is, he says, no impression of self, and therefore no idea of self.... (HWP, p. 662: IO-II; Russell's emphasis)

Now is this what is actually said by Hume? Take the first part of the

Hume's Labyrinth, I attempt to show how vital the appendix is in efforts to grasp and assess Hume's views on the self in the main text of the Treatise.

5 Three additional major elements of Russell's interpretation can also be identified. As Russell sees it, in his view of the self Hume also subscribes to the following broad theses:

- Statements about impressions do not presuppose any ontological commitments to the self.

- The term "self" only refers to a set of impressions.

- No knowledge of a substantial self is possible.

I will not explicitly consider these suggestions from Russell here, as interesting as they might be. 
suggestion from Russell - that for Hume, there is no impression of the self.

The citation Russell provides for this attribution is puzzling: Book I, Part IV, Sec. VI. That is to say, the entire section on personal identity is regarded by Russell as the source for his proposal here on Hume's thoughts on ideas and impressions of the self ! The texts do not appear to support this suggestion from Russell. The section cited here by Russell does not explicitly state that there is no impression of the self, and, to the best of my knowledge, this statement is not presented elsewhere in the Treatise. ${ }^{6}$ What is more, Hume certainly does not devote the entire section "Of personal identity" to an elaboration of this assertion. ${ }^{7}$ To make matters worse, when Russell is more forthright on this point in providing us with what he views as direct textual support for his claim that for Hume "there is ... no impression of self", the quotation he produces does not lend direct support for it. For the material Russell assembles to substantiate his interpretation appears to support a different claim from Hume on the evasiveness of the self - that is to say, nothing is explicitly said on the absence of the impression of the self. A mere two sentences from the Treatise are used by Russell to show that Hume asserts that there is no impression of the self:

For my part, when I enter most intimately into what I call myself, I always stumble on some particular perception or other, of heat or cold, light or shade, love or hatred, pain or pleasure. I never catch myself at any time without a perception, and never can observe anything but the perception. (662: I I-I6; my underlining, Hume's italics ${ }^{8}$ )

${ }^{6}$ My suspicions coincide with some electronic evidence. A Google search on the phrase "(no) impression of self", with the single exception of the instance noted in the next footnote, comes up empty when one searches Hume's Treatise electronically. The text has been retrieved by researchers at McMaster University and made available online in their Archive for the History of Economic Thought.

7 In the appendix, which Russell appears to have overlooked, Hume does come close to saying this, for he asserts that "[e]very idea is deriv'd from preceding impressions; and we have no impression of self or substance, as something simple and individual" (Treatise, p. 633; my emphasis). But this is not explicitly to suggest that there is no impression of self-only that there is none with the characteristics of being simple and individual.

${ }^{8}$ As the Editor has kindly pointed out, the inability to perceive oneself resonated strongly with Russell. There are many allusions in his work to this human failing. Here 
This brief extract does not lend direct support to Russell's interpretation on Hume's view on an impression of the self. The quotation from the Treatise is about Hume's failure to find his self, and his inability to escape his perceptions. There is absolutely nothing here from Hume concerning questions on the impression of the self, as Russell maintains, and certainly nothing here on the forthright, broad thesis that there is no impression of the self. Is Russell misreading Hume? Surely not. ${ }^{9}$

Hume's remarks here on his failure to perceive the self, in spite of his persistent attempts to do so, and his observation that he "never can observe anything but the perception" are central to his analysis of the problem of the self. These comments are consistent with numerous suggestions elsewhere in the Treatise that we are unable to directly perceive postulated entities "behind" our impressions. This fundamental thesis is central to Hume's account of perception. As he stresses elsewhere, for instance, when analyzing our tendency to attribute properties to external physical objects, rather than to internal mental phenomena, Hume reminds us of our folly:

... properly speaking, 'tis not our body we perceive, when we regard our limbs and members, but certain impressions, which enter by the senses; so that the ascribing a real and corporeal existence to these impressions, or to their objects, is an act of the mind as difficult to explain, as that which we examine at present. (Treatise, Book I, Part IV, Sec. II: p. I9I)

are a few strands from the bundle of references to this insight. In TK Russell suggests that "Hume's inability to perceive himself was not peculiar, and I think most unprejudiced observers would agree with him" (Papers 7: 36). This shortcoming is also alluded to in Russell's brief paper, "Do Human Beings Survive Death?" (Papers 29: 70). In a previously unpublished essay, "Hume", Russell reminds us that Hume's observation on the evasiveness of the self forms the basis of his banishment of the term "substance" from philosophy altogether, "which it had dominated for two thousand years" (Papers II: 236).

9 Why is it unlikely that Russell is misreading Hume here on impressions? In the first place, this is a crucial component in Hume's argument. Accounts of Hume's views on the self, its idea and its impressions would need to do justice to this important thesis. Secondly, Russell is certainly not a novice at explicating the views of other philosophers at this stage in his career. And when the views are those from philosophers whom Russell holds in high regard, such as Hume, he is surely bound to present those views accurately. 
In modern parlance, Hume is here articulating and defending the "veil of perception" thesis: we perceive impressions directly, not the purported entities associated with the impressions. Now it would be ironic had Russell overlooked this vital distinction in his account of Hume's views on the self. The author of The Problems of Philosophy, for instance, is well aware of the need to distinguish between the perception of impressions, or sense-data, and the alleged perception of the entities responsible for the sense-data. As he famously pointed out in the opening chapter, "Appearance and Reality", we must maintain a healthy distinction between the two:

... the real table, if there is one, is not the same as what we immediately experience by sight or touch or hearing. The real table, if there is one, is not immediately known to us at all, but must be an inference from what is immediately known. ( $P P_{3}$, pp. 3-4; Russell's emphasis)

The parallels between Russell and Hume on this thesis are striking. It appears that Russell subscribes to the very same fundamental thesis on perception that lies at the heart of Hume's analysis. Why then does Russell conflate this distinction in his analysis of Hume's account of the self? That is to say, why does Russell apparently overlook Hume's basic insight that one can have perceptions of impressions but not of the entities that are alleged to cause these impressions? This is an important question, the consideration of which will lead us, so I think, to a deeper appreciation of Russell's understanding of Hume's views on the self.

At first blush it is difficult to say why Russell appears not to be sufficiently circumspect in his characterization of Hume's account of impressions. Of course, one plausible explanation is that Russell is too hasty in his depiction of Hume's account of the self. Such haste might account for Russell's "negligence”. This uncharitable interpretation strikes me as unconvincing, especially when one takes into account what Russell says later on Hume's attempt to solve the problem of the self. ${ }^{10}$ So if the conflation is not due to negligence, perhaps it is due to

${ }^{10}$ I am alluding to Russell's later remarks on definitions in attempts to solve the problem of the self. This will be dealt with in section II below. 
the brevity of the presentation? Has Russell oversimplified Hume's account of the self? This explanation is also wanting.

Admittedly, one cannot do a great deal with a mere seventeen sentences. And yes, simplification comes at a price. Perhaps the conceptual niceties in Hume's account of the self call for a more substantial set of linguistic tools than Russell appears to muster in his History. Nevertheless, the suggestion that the brevity of Russell's interpretation accounts for the conflation overlooks an important suggestion later from Russell: namely, that what we say can be rephrased in such a way that contentious references to questionable entities can be done away with in our philosophical discourse:

... we can always state what we know empirically without introducing any unperceived things or occurrences.

(662: $35-6)$

I think that this fundamental thesis underscores Russell's depiction of Hume's account of impressions of the self and may help us understand why he appears to conflate references to impressions and entities associated with the impressions. Russell's adoption of the proposal that "[i]deas of unperceived things or occurrences can always be defined in terms of perceived things or occurrences"-a suggestion that is not explicitly articulated by Hume-can be shown to account for the conflation (662: $32-4)$. My suspicion is that Russell is applying this dictum to the expression of his own interpretation of Hume's account of the problem of the self. With this proposal from Russell on operational definitions it becomes clear why he is able and willing to rephrase Hume's account of the self, especially his view on impressions of the self, in a manner that might initially be regarded as misleading. Talk about the self, for Russell, is to be regarded as equivalent to talk about the impressions associated with the self, and vice versa. So perhaps the discrepancy between the quotation from the Treatise above and Russell's interpretation is not as wide as I initially suggested. What now of the second major pillar of Russell's interpretation of Hume's views on the self; namely that the Treatise promotes the view that there is no idea of the self? Has this proposal any merit? 
The suggestion from Russell that Hume denies that there is an impression of the self is contentious, yet not implausible, provided that one makes a few (not unreasonable) concessions, as I have pointed out above. What now of the proposal that Hume denies that there is an idea of the self? What are the merits of this interpretation of Hume's views?

Of all the explicit and implicit interpretative proposals from Russell on Hume's views of the self, this must rank as the most problematic. As I shall demonstrate below, the text from the Treatise does not directly support this suggestion, no matter how one looks at it. Naturally, we need to revisit Hume's actual remarks on this issue in detail and hold Russell's proposal against the Treatise on this issue. But before we do so, I would like to draw attention to a number of purported consequences of this thesis, as Russell sees them. He identifies three interesting implications of this alleged "repudiation of the idea of the Self" (662: 22). As I shall show, Russell adopts an ingenious procedure to substantiate his interpretation of Hume on the idea of the self-he relies on an argument built around a consideration of these consequences to show that Hume denies that there is an idea of the self.

The denial that there is an idea of the self, for Russell, would be "of great importance”. Important issues in three different fields in philosophy stand to benefit from this result:

This conclusion is important in metaphysics, as getting rid of the last surviving use of "substance". It is important in theology, as abolishing all supposed knowledge of the "soul". It is important in the analysis of knowledge, since it shows that the category of subject and object is not fundamental. In this matter of the ego Hume made an important advance on Berkeley.

(663: 7-I2)

This is a surprising list of implications from Russell. As I see them, these appear to be three fundamentally different implications of Hume's thesis. Let us take a closer look at each of these suggestions. It is prudent to do this in order to gain a clearer understanding of Russell's reasons for proposing these implications of Hume's views. While he does not elaborate on any of them, we can add a few 
plausible speculative remarks on each implication to better appreciate Russell's assessment that these implications are significant for philosophy.

The first suggestion from Russell appears to be that Hume's denial that there is an idea of the self has a bearing on the word "substance": we can now get "rid of the last surviving use of [the word?] 'substance" (my insertion). If the word "self" is problematic, assumes Russell-for it lacks the requisite idea-the word "substance" is equally problematic. Notice that it is not self itself, or substance itself, that is banished by Hume, but the linguistic devices that we might be using to refer to these alleged referents. That this elaboration has some merit emerges from a consideration of the rest of the paragraph in which this implication is embedded. For here Russell is quick to point out that Hume has not argued that there is no self, i.e. he is not denying that there is a simple substance that we call the self- this strong implication would flaunt the epistemological restrictions on what we can possibly know. From Hume's thesis on the idea of the self, it

... does not follow that there is no simple Self; it only follows that we cannot know whether there is or not, and that the Self, except as a bundle of perceptions, cannot enter into any part of our knowledge. (663:4-7)

So Hume is an agnostic about the self, for Russell. It might exist, but even if it does, we are unable to acquire any direct knowledge of it. So scepticism about the self is apt. The best that we can do is study the perceptions reputed to be associated with it. ${ }^{11}$ So the restrictions on what we can possibly know about the substantial self places severe limitations on the word that we are tempted to rely on when attempting to refer to this evasive substance. For all intents and purposes this word is useless, as are other related words-hence Russell's proposal that Hume's thesis enables us to get "rid of the last surviving use of [the related term] 'substance'” (663: 8).

So much for my suggestion on how to read Russell's proposal on

${ }^{11}$ Pears, in Bertrand Russell and the British Tradition in Philosophy, points out that for Russell the ego is a logical construction: "Indeed, the ego has to be analysed into a series of events which actually include the appearances which were supposed to be given to it” (p. 4I). In other words, as Hume might also put it, the ego or self is a collection or bundle of perceptions that constitute the mind. 
the implication of Hume's thesis for the word "substance". What about the second proposal from Russell-that the thesis that there is no idea of the self "is important in theology, as abolishing all supposed knowledge of the 'soul'" (663: 8-9). This implication appears to be very different from the previous one. The focus of Russell's remarks is now on the alleged knowledge one assumes can be obtained on the purported soul, or the self, to use Hume's preferred terminology. While one might be under the impression that one is acquiring knowledge of the soul, or self, no genuine knowledge can form of the self because the self is not directly accessible. The best that we can acquire is direct knowledge of a collection of perceptions thought to be associated with the self. But these perceptions-of the self?-are different from the (alleged) self. So the attempt to learn about the self from a study of the perceptions is fraught with problems. Hence Russell's suggestion that if there is no idea of the soul, or self, no knowledge - that is to say, no direct or certain knowledge-can be formed of this entity.

The third and final implication of Hume's alleged thesis that there is no idea of the self apparently is the proposition that "the category of subject and object is not fundamental" (663: IO-II). This insight from the analysis of Hume's account of the self echoes Russell's earlier, I900 investigation of Leibniz's questionable metaphysics, with its uncritical embrace of the subject-predicate analysis of propositions. As with the first two alleged implications that Russell identifies in his History, no elaboration is provided of this possibility. So we need to be cautious in our explication of this proposal. Nevertheless, it seems reasonable to suggest that if there is no idea of the self, the idea of an individual or subject who is presumed to possess a self will be equally compromised. Hence the attempt to distinguish between subject and object will require ad hoc hypotheses or explications entailing that the concepts of subject and object are not as pristine, self-evident or basic as one might wish them to be.

As Russell cryptically puts it, "the category of subject and object is not fundamental" if Hume's alleged thesis is accepted-i.e., these concepts still call for further explication.

It is clear that Russell gains from the thesis that there is no idea of the self. But is this thesis true? And perhaps equally important for us, does Hume actually support this view? Take the first question. 
Suppose that we grant that the view that there is no idea of the self has wide ramifications. Why accept it in the first place? Russell addresses this important issue in his own spare seventeen sentences on Hume's account of the self, summing up Hume's reasoning in one sentence:

To begin with, the Self, if there is such a thing, is never perceived, and therefore we can have no idea of it.

(662: 22-5)

This argument needs to be unpacked and held against Hume's views. ${ }^{12}$

The following exegesis seems a plausible rendition of Russell's proposal:

[Premiss I:] The Self ... is never perceived.

[Conclusion:] We can have no idea of [the Self ].

(662: 24-5; my emphases)

This argument assumes that we can only have ideas of entities that are perceived, and as the self is not one of these perceived entities, it is not possible for an idea of the self to form. Furthermore, this argument relies on an inference from fact to possibility: from the observation that, as a matter of fact no self is ever perceived, Russell suggests that Hume infers that no idea can possibly result. The inference is questionable, and on the face of it, patently false. This line of reasoning is akin to the proposal that as the dark side of the moon has never been seen by Prince Charles, the dark side of the moon can never be seen. Or to put it more pointedly: since $A$ has never seen $X$, it might be concluded

${ }^{12}$ My suggestion here assumes that Russell is actually presenting us with an argument and not a conditional statement. The conclusion indicator "therefore", as well as Russell's own remarks on this sentence, lend support to the former proposal. For he says this immediately after presenting the sentence: "If this argument is to be accepted it must be carefully stated" (662: 16; my emphasis). But this might not be how Hume sees matters. Perhaps Russell is reading too much into the relationship between the suggestion that no self is perceived and the proposal that "we can have no idea of it". This would not be the first time that a logical relationship important in the history of philosophy was misconstrued. To give one example: Descartes' claim, "I think, therefore I am", has spawned much debate among historians of philosophy. Is this an argument or a conditional statement? The textual evidence appears to be ambiguous. 
that we can have no idea of $X$. Of course, this argument as it stands is invalid, for it does not follow that $X$ cannot be perceived merely from the fact that $X$ has not been perceived to date. But Russell does not draw attention to any logical problems in what he views as Hume's argument. Far from it!

As I pointed out above, Russell suggests that the conclusion of the argument that he attributes to Hume has at least three important implications, for metaphysics, theology and epistemology respectively. Russell strongly endorses these implications. As he puts it when summing up these beneficial outcomes, "In this matter of the ego Hume made an important advance on Berkeley" (663: II-I2). So Russell views the implications as important - that is to say, as significant and, therefore, as true. From this it follows that he regards Hume's argument on ideas as valid, even though on the surface it appears to be invalid. How do we account for this enigma?

Has Russell missed the opportunity to point out the invalidity in Hume's reasoning? Perhaps he did not even notice it? Surely not. The suggestion that the co-author of Principia Mathematica has not noticed the defects in a simple line of reasoning that features centre stage in his History's presentation of an important figure from the history of western philosophy strikes me as implausible. No. The answer must surely be found elsewhere. It lies, I suggest, in Russell's elucidation of the argument he attributes to Hume. Unless this argument is carefully presented, warns Russell, it will not be accepted, i.e. it will be summarily dismissed as invalid: "If this argument is to be accepted, it must be carefully stated" (662: 25-6). So what is gained from Russell's explanation that "rescues" the apparently invalid argument from Hume? In a word, it is a definition. More specifically, the application of an operational definition for the term "self" rescues the argument from the charge of invalidity. We need to take a closer look at Russell's attempt to save Hume's argument. ${ }^{13}$

${ }^{13}$ Some readers might object to my use of the term "save". Perhaps Russell is not deliberately setting out to rescue Hume from the charge of invalidity in his explication. Nevertheless, his reliance on the operational definition of "self", as I will show shortly, makes it that much more difficult to fault Hume's reasoning on this score. Even if Russell's moves are unintentional, the addition of the operational definition of "self" provides the argument with initial plausibility and consequently makes what appear to be Hume's views plausible as well. 
In his explication of Hume's views on the self Russell makes much of an instance where an operational definition can be usefully used. The example involves the reference to a man and his brain. Individuals do not perceive their brains, Russell points out, yet they are able to think and talk sensibly about these unperceived entities.

No man perceives his own brain, yet, in an important sense, he has an "idea" of it. Such "ideas", which are inferences from perceptions, are not among the logically basic stock of ideas; they are complex and descriptive- this must be the case if Hume is right in his principle that all simple ideas are derived from impressions....

(662: 26-30)

This is a puzzling example that warrants closer scrutiny. Russell is reminding us of the fundamental thesis from Hume on the relationship between simple ideas and impressions: impressions constitute the source of these basic ideas. Now we appear to have ideas of our (unperceived) brains. But, unfortunately, we do not have impressions of these brains - well, not in any obviously straightforward manner, suggests Russell. So if we have ideas of our brains, these ideas must differ in a fundamental way from our regular ideas - those that form part of the "basic stock of ideas", as Russell cryptically puts it. Hence talk about the brain differs in a fundamental way from talk about other entities that are associated with ideas from the "basic stock of ideas". This talk about the (unobserved) brain must be inferential, relying on the prior existence of ideas of entities that have been directly observed. So language about the unobserved brain, and for that matter the unobserved self, can make sense provided that more basic language about observed entities is associated with ideas that come from the "basic stock of ideas". In short, if we can construct operational definitions for problematic terms-for instance, the terms "brain" and "self"- those terms can be relied on in our philosophical and presumably regular discourse. Hence Russell's general remark that

Ideas of unperceived things or occurrences can always be defined in terms of perceived things or occurrences, and therefore, by substituting the definition for the term defined, we can always state what we know empirically without introducing any unperceived things or occurrences.

(662: 32-6) 
All of which suggests that when Russell boldly informs the readers of his History that Hume denies that there is an idea of the self, he is saying that Hume is actually denying that this idea can be found among the stock of "basic ideas" that have been produced by our impressions. But this still leaves open the possibility that there is an idea of the self for Hume among those ideas that are not basic: a non-basic idea that legitimizes the use of the word "self" in informed or circumspect philosophical discourse. So talk about the self, as with talk about the brain, could be meaningful and legitimate and need not presuppose any ontological entanglements because the words "self" and "brain" are associated with their respective non-basic ideas. Is this how Hume views the matter?

I think so, to a large extent. After a compact opening paragraph in the section "Of personal identity" on his rivals' bold pronouncements on the self, Hume has this to say on the idea of the self:

Unluckily all these positive assertions are contrary to that very experience, which is pleaded for them, nor have we any idea of self, after the manner it is here explain'd.

(Treatise, p. 25I; Hume's emphasis)

The idea of the self that may actually exist, Hume informs us here, differs from the philosophers' purported idea of the self. In Russell's parlance, Hume is claiming that the idea of the self that actually exists is not from the basic stock of ideas-i.e., from those ideas directly associated with impressions. If there is such an idea, it must be fundamentally different from our more basic ideas. Hence talk about the elusive self-which for Russell is akin to talk about unobserved entities, like our brains-must be conducted with great circumspection. Without the requisite caution we are likely to be swept along fanciful pathways fraught with (unnecessary) ontological encumbrances.

So the argument that Russell outlines and relies on when explicating Hume's views on the idea of the self appears to be consistent with the text. As Russell sees it, Hume is not denying that there is an idea of the self. Instead, Hume is proposing a more nuanced view of the idea of the self, according to which this idea is not a basic idea, but a more refined philosophical idea that relies on inferences and analyses of the more fundamental ideas produced by our impressions. What this nonbasic idea consists of and how it comes into existence are issues that 
Russell does not address in his History of Western Philosophy. Given what he has delivered in his terse twenty sentences on Hume's views on the self, this lacuna is surely not to be denounced. ${ }^{14}$

${ }^{14}$ I would like to thank the two anonymous referees for their constructive suggestions on an earlier version of this paper.

APPENDIX: COMPLETE PASSAGE FROM

"A HISTORY OF WESTERN PHILOSOPHY"

\section{[P. 662]}

Hume banished the conception of substance from psychology, as 10 Berkeley had banished it from physics. There is, he says, no impression of self, and therefore no idea of self (Book I, Part IV, Sec. vi). "For 12 my part, when I enter most intimately into what I call myself, I always stumble on some particular perception or other, of heat or

14 cold, light or shade, love or hatred, pain or pleasure. I never catch myself at any time without a perception, and never can observe anything but the perception." There may, he ironically concedes, be some philosophers who can perceive their selves; "but setting aside

18 some metaphysicians of this kind, I may venture to affirm of the rest of mankind, that they are nothing but a bundle or collection of dif-

20 ferent perceptions, which succeed each other with inconceivable rapidity, and are in a perpetual flux and movement."

22 This repudiation of the idea of the Self is of great importance. Let us see exactly what it maintains, and how far it is valid. To begin with, 24 the Self, if there is such a thing, is never perceived, and therefore we can have no idea of it. If this argument is to be accepted, it must be

26 carefully stated. No man perceives his own brain, yet, in an important sense, he has an "idea" of it. Such "ideas", which are inferences from

28 perceptions, are not among the logically basic stock of ideas; they are complex and descriptive - this must be the case if Hume is right

30 in his principle that all simple ideas are derived from impressions, and if this principle is rejected, we are forced back on "innate" ideas. Using 32 modern terminology, we may say: Ideas of unperceived things or occurrences can always be defined in terms of perceived things or occurrences, and therefore, by substituting the definition for the term defined, we can always state what we know empirically with36 out introducing any unperceived things or occurrences. As regards our present problem, all psychological knowledge can be stated with- 


\section{[P. 663]}

out introducing the "Self". Further, the "Self", as defined, can be 2 nothing but a bundle of perceptions, not a new simple "thing". In this I think that any thoroughgoing empiricist must agree with Hume.

4 It does not follow that there is no simple Self; it only follows that we cannot know whether there is or not, and that the Self, except as 6 a bundle of perceptions, cannot enter into any part of our knowledge. This conclusion is important in metaphysics, as getting rid of

8 the last surviving use of "substance". It is important in theology, as abolishing all supposed knowledge of the "soul". It is important in

10 the analysis of knowledge, since it shows that the category of subject and object is not fundamental. In this matter of the ego Hume made 12 an important advance on Berkeley.

\section{WORKS CITED}

Broackes, Justin. "Hume". In Ted Honderich, ed. The Philosophers. Oxford: Oxford U. P., 200 I.

Hume, David. A Treatise of Human Nature. Ed. L. A. Selby-Bigge. 2nd edn. Oxford: Clarendon P., I896 (repr. I978). Earlier edition online: http:// socserv.mcmaster.ca/econ/ugcm/31l3/ hume/

Monk, Ray. Bertrand Russell, [Vol. 2:] I921-70, the Ghost of Madness. New York: Free P., 200 I.

Pears, David. Bertrand Russell and the
British Tradition in Philosophy. New York: Random House, 1967; 2nd edn., London: Collins/Fontana, I972.

Russell, Bertrand. TK. Papers 7.

-. PP.

-. $H W P$.

-. "Hume" (1946). Papers II: 3I.

-. "Do Human Beings Survive Death?" (1957). Papers 29: 15.

Schwerin, Alan. Hume's Labyrinth: a Search for the Self. Newcastle upon Tyne: Cambridge Scholars Publishing, 2012. 